\title{
Life-history patterns of fishes in the Hellenic Seas
}

\author{
Konstantinos I. Stergiou
}

Stergiou, K.I. 2000. Life-history patterns of fishes in the Hellenic Seas. - Web Ecology 1: $1-10$

\begin{abstract}
The available quantitative information (age, growth, maturation and mortality) for 103 fish stocks in Hellenic Seas was analysed here in the context of life-history theory and compared with similar information from other areas of the world.

The results showed that the fish species and stocks inhabiting Hellenic waters are generally small in size, have low longevity, mature at an early age and size, and probably suffer high adult mortality rates. Such a pattern most probably is an adaptation to the synergetic combination of highly oligotrophic conditions and high subtropical temperatures prevailing in Hellenic waters and is consistent with life-history theory.

Finally, the auximetric grid was used to compare the growth of four species, each represented by more than six stocks. The results revealed that the growth spaces occupied by the four species reflect their strikingly different feeding habits, especially with respect to the size of prey and the relative importance of fish prey to their diet.
\end{abstract}

K.I. Stergiou, Aristoteleio University, School of Biology, Department of Zoology, Laboratory of Ichthyology, PO Box 134, Thessaloniki, GR 54 006, Hellas (e-mail address: kstergio@bio.auth.gr)

The study of life-history theory is of fundamental importance to the analysis of population performance and thus to both theoretical ecology and resource management. Life-history theory is based on the concept of trade-off constraints between alternative energy-consuming functions, and the resulting balance between life history traits tends to maximize fitness (i.e. total reproductive output) (e.g. Beverton 1963, Roff 1992, Stearns 1992, Charnov 1993). When various life-history parameters (e.g. growth, maturation and mortality) are plotted against each other for a large number of fish species, clear patterns emerge (e.g. Pauly 1998a, Froese and Pauly 1998). Thus, for instance, tropical fishes are smaller, attain their asymptotic sizes faster, have for any given asymptotic size higher natural mortality, and have higher trophic levels than their colder counterparts (Pauly 1998a). Several empirical studies on fishes have shown that some of the emerging patterns are consistent with the trade-off concept (e.g. negative correlations between current reproduction and some component of fitness, usually survival of offspring, mortality and growth: Adams 1980, Pauly 1980, Gunderson and Dygert 1988, Wootton 1990, Jennings and Beverton 1991, Stearns 1992, Roff 1992, Pauly 1998a).

Stergiou et al. (1997) reviewed the available quantitative information on the physics, chemistry, biology and fisheries of the Hellenic Seas. The available data clearly indicate the highly oligotrophic nature of the subtropical Hellenic waters, with large areas being directly comparable, in terms of trophic potential, to open oceans. Since temperature and the quality and quantity of food are among the most important factors affecting phenotypic responses in fishes (e.g. Wootton 1990, Jennings and Beverton 1991, Roff 1992), one may predict, based on lifehistory theory (e.g. Adams 1980, Stearns 1992, Roff 1992, Charnov 1993, Pauly 1998a, Froese and Pauly 1998), that the fish stocks and/or species inhabiting Hellenic waters will be generally smaller in size, have lower longevity, mature at an earlier age and size, and probably suffer higher 
adult mortality rate than their counterparts in other areas of the world.

Fisheries research in Hellenic waters has been conducted on a systematic basis (i.e. properly designed seasonal surveys) since the early 1980s within the framework of various projects financed either by National or European Union sources. Stergiou et al. (1997) also reviewed the available quantitative information on the age, growth, maturity and longevity for 103 fish stocks in the Hellenic Seas. Such information was used here to test the above-mentioned predictions, being compared with similar information from other areas of the world that was used as background.

\section{Material and methods}

Data were obtained for the following life-history parameters for 103 Hellenic fish stocks:

(a) The maximum reported length and age, $\mathrm{L}_{\max }$ and $\mathrm{T}_{\mathrm{max}}$, in $\mathrm{cm}$ and $\mathrm{yr}$ respectively.

(b) The female length-at-maturity, $\mathrm{L}_{\text {mat }}$, in $\mathrm{cm}$.

(c) The female age-at-maturity, $\mathrm{T}_{\mathrm{mar}}$, in $\mathrm{yr}$.

(d) The von Bertalanffy (1938) growth parameters K, $\mathrm{L}_{\mathrm{oo}}$ and $\mathrm{t}$, in $\mathrm{yr}^{-1}, \mathrm{~cm}$ and $\mathrm{yr}$, respectively.

(e) The natural and total (i.e. natural plus fishing) mortality rates, $\mathrm{M}$ and $\mathrm{Z}$, respectively, in $\mathrm{yr}^{-1}$.

The 103 fish stocks belonged to 40 species, 20 families and 7 orders:

Clupeiformes: 1 stock, 1 species;

Lophiiformes: 4 stocks, 2 species;

Cyprinodontiformes: 7 stocks, 1 species;

Gadiformes: 20 stocks, 7 species;

Pleuronectiformes: 8 stocks, 4 species;

Scorpaeniformes: 6 stocks, 5 species; and

Perciformes: 57 stocks, 20 species) (see Appendix for species names).

The word "stock" is used here to indicate sets of parameters corresponding to different sexes, years and areas. The above mentioned parameters were consequently used for the estimation of the relationships between $\mathrm{K}$ and $\mathrm{L}_{\mathrm{oo}}, \mathrm{K}$ and $\mathrm{T}_{\text {max }}, \mathrm{L}_{\text {max }}$ and $\mathrm{L}_{\mathrm{oo}}$, and $\mathrm{Z}$ and $\mathrm{T}_{\text {max }}$, as well as for the estimation of the $\mathrm{L}_{\text {mat }}{ }^{\circ} / \mathrm{L}_{\mathrm{oo}}$, and $\mathrm{L}_{\text {max }} / \mathrm{L}_{\mathrm{oo}}$ ratios. All these relationships and ratios are important in the context of lifehistory theory (e.g. Beverton and Holt 1959, Longhurst and Pauly 1987, Jennings and Beverton 1991, Stearns 1992, Roff 1992, Charnov 1993, Pauly 1994, 1997, 1998a,b, Froese and Pauly 1998).

The estimation of the parameters reviewed herein has been mainly based on field data derived from experimental seasonal surveys (see Stergiou et al. 1997, for a detailed description). Age and growth have been studied either from readings of various hard elements (i.e., otoliths, scales, and spines) or from length-frequency analysis. Body length measurements refer mainly to total length (59 stocks) and fork length (35 stocks; standard length was used for 9 stocks only).

Growth in length has been described using the von Bertalanffy (1938) growth equation, based either on observed or back-calculated length-at-ages. The von Bertalanffy (1938) growth equation is:

$$
\mathrm{L}_{\mathrm{t}}=\mathrm{L}_{\mathrm{oo}}\left(1-\mathrm{e}^{(-\mathrm{K}(\mathrm{t}-\mathrm{to})}\right),
$$

where $L_{t}$ is the length of fish at age $t, L_{o o}$ is the asymptotic length (i.e., the length a fish would reach if it was to grow indefinitely according to the model), $\mathrm{K}$ is the growth coefficient (the curvature index), showing how fast a fish approaches its $\mathrm{L}_{\mathrm{oo}}$, and $\mathrm{t}_{\mathrm{o}}$ is a small negative or positive number representing the age a fish would have at zero length.

Natural mortality rates $(\mathrm{M})$ have been estimated using the empirical formula of Pauly (1980) and $\mathrm{Z}$ rates using mainly the length-converted catch-curve (Pauly 1983). $\mathrm{T}_{\text {mat }}$ was estimated by the present author from the $\mathrm{L}_{\text {mat }}$ values and the corresponding von Bertalanffy parameters. Data on $\mathrm{L}_{\mathrm{o}}, \mathrm{K}$, female $\mathrm{L}_{\text {mat }}$, and female $\mathrm{L}_{\text {mat }} / \mathrm{L}_{\mathrm{oo}}$ for a wide variety of fish species from other areas of the world were also extracted from FishBase 98 (The PopGrowth table: Binohlan and Pauly 1998; The Maturity table: Binohlan 1998), the largest computerised encyclopaedia of fishes. Such data are documented in FishBase tables via a link to the reference from which the parameter values were extracted (Froese and Pauly 1998) and are very useful in lifehistory studies (Pauly 1998a, Pauly et al. 1998).

Although various authors use the von Bertalanffy (1938) K parameter as an index of growth rate (e.g. Roff 1992, Francis 1996), it is well known that neither K nor $\mathrm{L}_{\mathrm{oo}}$ has the dimensions of growth (i.e. length/time; Pauly et al. 1996). This has led to the development of different combinations of these two parameters, among which the growth indices $\varphi^{\prime}=\log \mathrm{K}+2 \log \mathrm{L}_{\mathrm{oo}}$ and $\varphi=\mathrm{Log} \mathrm{K}+(2 / 3)$ LogW (Munro and Pauly 1983, Pauly and Munro 1984) have the lion's share in the literature, being widely used for comparing fish and invertebrate growth (e.g. Moreau et al. 1986, Vakily 1992). Recently, Pauly et al. (1996) proposed the auximetric grid as another tool for the comparison of within- and between-species growth performances. The auximetric grid is a plot of the $\operatorname{LogK}$ values versus the $\log \mathrm{L}_{\mathrm{oo}}$ values for different stocks (or populations) of a species (Pauly et al. 1996). In such a plot, a single $\mathrm{L}_{\text {oo }}-\mathrm{K}$ point represents a stock, whereas the different stocks of the same species form a cluster of points covered by an ellipse with a surface area related to the variance of the two parameters plotted. The surface area expressing the growth space occupied by a given species can be independent of the number of $\mathrm{L}_{\mathrm{o}}-\mathrm{K}$ pairs when the latter is higher than a critical number $(>6)$. This is achieved through a simple resampling method developed by Pauly et al. (1996), according to which ellipses with circumference containing the $95 \%$ 
confidence area of a cluster of $\mathrm{L}_{\mathrm{oo}}-\mathrm{K}$ pairs are estimated. In the present study, ellipses and asymptotic surfaces, $S_{o o}$, were obtained through resampling and plotted using AUXIM (Pauly et al. 1996) for four species only (Aphanius fasciatus, Mullus barbatus, Merluccius merluccius and Xiphias gladius), each represented by more than six stocks. Overlap between growth spaces was quantified in the form of an overlap index between pairs of ellipses (Pauly et al. 1996). The values of the overlap index range from 0 , when the two ellipses are completely separated, to 1 , when the smaller of two ellipses is contained completely within the larger one.

\section{Results}

Table 1 summarises the statistical properties of the various life history parameters for the 103 fish stocks in Hellenic waters. $\mathrm{L}_{\max }$ (Fig. 1a) ranged between $5.8 \mathrm{~cm}$, for Aphanius fasciatus, and $225 \mathrm{~cm}$, for Xiphias gladius, and $\mathrm{T}_{\text {max }}$ (Fig. 1b) between 3 yr, for Liza aurata, and 13 yr, for Merlangius merlangus euxinus and Pagellus erythrinus. Female $\mathrm{L}_{\text {mat }}$ (Fig. 1c) was available for 36 stocks only and ranged from 8.9 $\mathrm{cm}$, for Spicara smaris, to $43 \mathrm{~cm}$, for Merluccius merluccius.

The von Bertalanffy growth parameters were available for 99 stocks only. K values (Fig. 2a) ranged from $0.062 \mathrm{yr}^{-}$ ${ }^{1}$, for $M$. merluccius, to $3.066 \mathrm{yr}^{-1}$, for S. smaris, $\mathrm{L}_{\mathrm{oo}}$ values (Fig. 2b) from $7.6 \mathrm{~cm}$, for $A$. fasciatus, to $244 \mathrm{~cm}$, for $X$. gladius, and t values (Fig. 2c) from -3.95 yr, for Spicara flexuosa, to $2.83 \mathrm{yr}$, for Pagrus pagrus.

A negative relationship between $\log \mathrm{L}_{\text {o }}$ and $\operatorname{LogK}$ was identified for five species only (Mullus barbatus, Mullus surmuletus, Trisopterus minutus capelanus, $X$. gladius, and $A$. fasciatus), represented by four or more stocks (Table 2). The values of the slopes were significantly different from 0 $(\mathrm{P}<0.05)$ and ranged between 0.18 and 0.60 (Table 2). In contrast, a negative but not significant relationship was found between $\log \mathrm{L}_{\mathrm{oo}}$ and $\log \mathrm{K}$ for the different stocks of
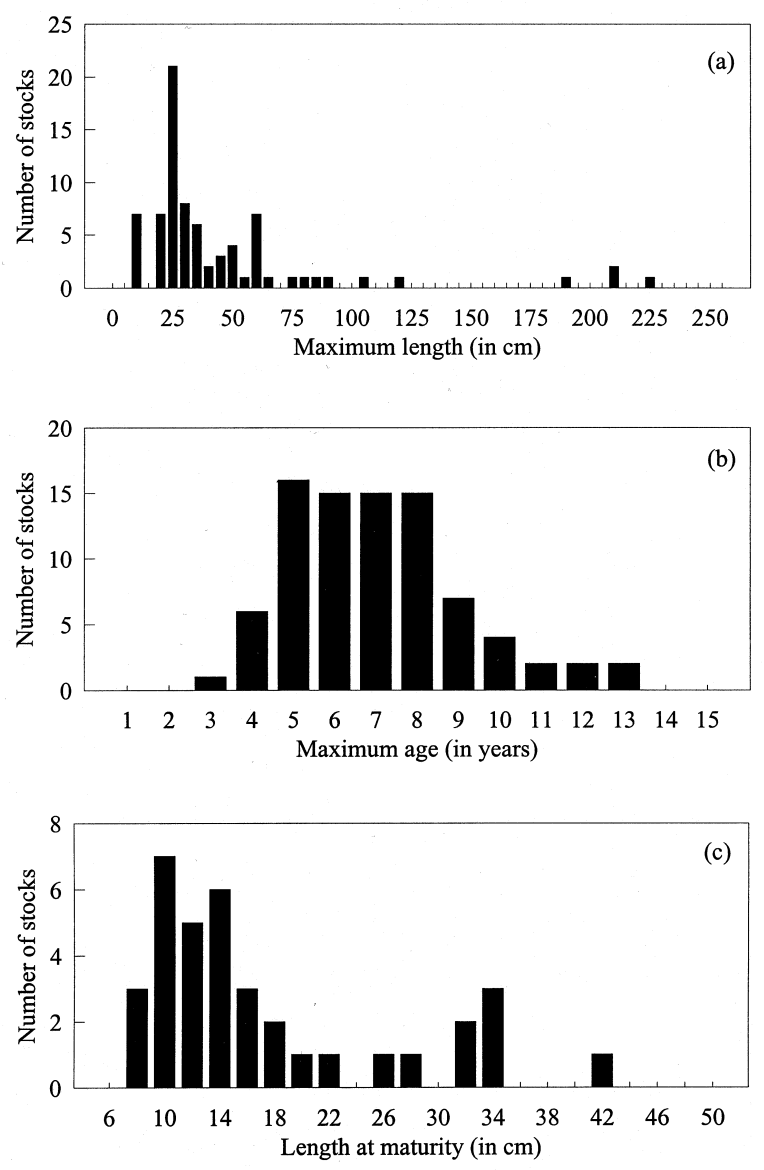

Fig. 1. (a) Maximum length, (b) maximum age and (c) length at maturity for a variety of fish stocks in Hellenic waters.

Table 1. Statistical analysis of various available life-history parameters of marine fishes in Hellenic waters. For symbols see material and methods. Original data set from Stergiou et al. (1997).

\begin{tabular}{|c|c|c|c|c|c|c|}
\hline Parameter & Minimum & Maximum & Mean & Stand. dev. & Median & Number \\
\hline $\mathrm{L}_{\max }(\mathrm{cm})$ & 5.8 & 225 & 43.6 & 44.28 & 27 & 77 \\
\hline $\mathrm{T}_{\max }^{\max }(\mathrm{yr})$ & 3 & 13 & 7.02 & 2.12 & 7 & 85 \\
\hline $\mathrm{L}_{\text {max }}^{\max }(\mathrm{cm})$ & 8.9 & 43.0 & 18.6 & 9.1 & 16.4 & 36 \\
\hline $\mathrm{K}(1 / \mathrm{yr})$ & 0.06 & 3.07 & 0.29 & 0.34 & 0.23 & 99 \\
\hline $\mathrm{L}_{\mathrm{oo}}(\mathrm{cm})$ & 7.6 & 243.8 & 48.8 & 51.9 & 32.1 & 99 \\
\hline $\mathrm{t}_{0}(\mathrm{yr})$ & -3.95 & 2.83 & -1.05 & 1.16 & -1.16 & 88 \\
\hline $\mathrm{L}_{\max }^{0} / \mathrm{L}_{\mathrm{oo}}$ & 0.56 & 1.34 & 0.90 & 0.15 & 0.90 & 74 \\
\hline $\mathrm{L}_{\mathrm{max}}^{\max } / \mathrm{L}_{\mathrm{oo}}^{\mathrm{oo}}$ & 0.33 & 0.74 & 0.49 & 0.12 & 0.48 & 24 \\
\hline $\mathrm{G}_{1}^{\mathrm{mat}}(\mathrm{cm})$ & 2.9 & 103.2 & 16.8 & 22.5 & 11.5 & 99 \\
\hline $\mathrm{G}_{1} / \mathrm{L}_{\mathrm{oo}}$ & 0.11 & 0.94 & 0.35 & 0.16 & 0.34 & 99 \\
\hline $\mathrm{T}_{\mathrm{mat}}^{1}(\mathrm{yr})$ & 1 & 6 & 2.5 & 1.14 & 2.3 & 24 \\
\hline $\mathrm{M}^{\mathrm{mat}}(1 / \mathrm{yr})$ & 0.16 & 1.91 & 0.51 & 0.38 & 0.37 & 53 \\
\hline $\mathrm{Z}(1 / \mathrm{yr})$ & 0.29 & 4.82 & 1.06 & 0.68 & 0.91 & 54 \\
\hline
\end{tabular}


Table 2. Regression equations between the von Bertalanffy (1938) growth parameters $\mathrm{K}$ and $\mathrm{L}_{\mathrm{o}}$, for five fish species in Hellenic waters. $\mathrm{SE}(\mathrm{b})$ is the standard error of the slope, $\mathrm{r}$ is the correlation coefficient, and $\mathrm{n}$ is the number of stocks per species. For all regressions, $\mathrm{P}<0.05$.

\begin{tabular}{|c|c|c|c|c|}
\hline Species & Regression & $\mathrm{SE}(\mathrm{b})$ & $\mathrm{r}$ & $\mathrm{N}$ \\
\hline Mullus barbatus & $\log \mathrm{L}_{\mathrm{oo}}=1.28-0.18 \mathrm{Log} \mathrm{K}$ & 0.07 & -0.66 & 11 \\
\hline Mullus surmuletus & $\log \mathrm{L}^{\circ \circ}=1.05-0.56 \mathrm{LogK}$ & 0.07 & -0.99 & 4 \\
\hline Trisopterus minutus capelanus & $\log \mathrm{L}_{\circ \mathrm{oo}}=1.07-0.60 \mathrm{Log} \mathrm{K}$ & 0.04 & -0.99 & 4 \\
\hline Xiphias gladius & $\log \mathrm{L}_{\mathrm{oo}}=2.17-0.26 \mathrm{Log} \mathrm{K}$ & 0.07 & -0.86 & 7 \\
\hline Aphanius fasciatus & $\operatorname{LogL}_{\mathrm{oo}}=0.59-0.47 \mathrm{Log} \mathrm{K}$ & 0.07 & -0.94 & 7 \\
\hline
\end{tabular}

M. merluccius $(\mathrm{r}=-0.59, \mathrm{n}=9, \mathrm{P}>0.05)$ and $S$. smaris $(\mathrm{r}=-$ $0.37, \mathrm{n}=6, \mathrm{P}>0.05)$. All remaining species were represented by less than four stocks. When stocks were grouped by family, a negative relationship was identified for Mullidae $\left(\log \mathrm{L}_{\mathrm{o}}=1.18-0.34 \mathrm{LogK}, \mathrm{SE}-\right.$-slope $=0.08, \mathrm{r}=-0.77, \mathrm{n}=15$, $\mathrm{P}<0.01)$. In contrast, a negative but not significant relationship was found for Centracanthidae $(\mathrm{r}=-0.14, \mathrm{n}=8$, $\mathrm{P}>0.05)$, Mugilidae $(\mathrm{r}=-0.66, \mathrm{n}=8, \mathrm{P}>0.05)$, Triglidae $(\mathrm{r}=-$ $0.34, \mathrm{n}=6, \mathrm{P}>0.05)$, Lophiidae $(\mathrm{r}=0.89, \mathrm{n}=4, \mathrm{P}>0.5)$, Sparidae ( $\mathrm{r}=-0.34, \mathrm{n}=7, \mathrm{P}>0.05)$, Merluccidae (same as for M. merluccius) and Gadidae $(\mathrm{r}=-0.33, \mathrm{n}=11, \mathrm{P}>0.05)$. Sim-
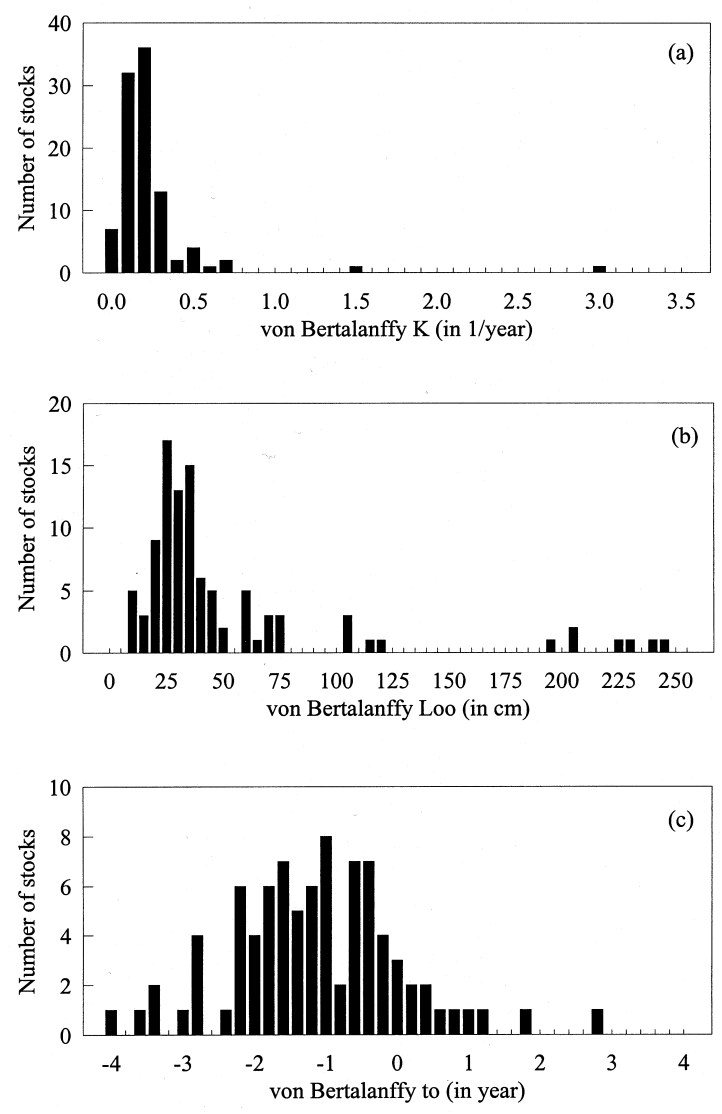

Fig. 2. The von Bertalanffy (a) $\mathrm{K}$, (b) $\mathrm{L}_{\mathrm{oo}}$ and (c) $\mathrm{t}_{\mathrm{o}}$ parameters for a variety of fish stocks in Hellenic waters. ilarly when species were grouped by order, a negative relationship was found only for Cyprinodontiformes (same as A. fasciatus) and Gadiformes ( $\log \mathrm{L}_{\mathrm{oo}}=1.12-0.67 \mathrm{LogK}, \mathrm{SE}-$ slope $=0.13, r=-0.77, n=20, P<0.001)$. In contrast, a negative, but not significant relationship was found for Perciformes $(r=-0.26, n=53, P>0.05)$, Pleuronectiformes $(r=-$ 0.68, $\mathrm{n}=8, \mathrm{P}>0.05)$ and Scorpaeniformes $(\mathrm{r}=-0.34, \mathrm{n}=6$, $\mathrm{P}>0.05$ ). Finally, for all species and stocks combined the following relationship was established: $\log \mathrm{L}=1.34$ $0.32 \mathrm{LogK}$ (SE-slope $=0.12, \mathrm{r}=-0.25, \mathrm{n}=99, \mathrm{P}<0.05$ ) (Fig. 3).

The slope of the $\log \mathrm{L}_{\mathrm{oo}}-\log \mathrm{K}$ relationship for all the available stocks in Hellenic waters was significantly (ANCOVA, $\mathrm{P}<0.05)$ smaller than that for all species so far included in FishBase 98 and for which von Bertalanffy estimates are available: $\log \mathrm{L}_{\mathrm{oo}}=1.36-0.57 \mathrm{LogK}$ (SE-slope $=$ $0.008, \mathrm{r}=-0.71, \mathrm{n}=4830, \mathrm{P}<0.001$; Fig. 4). From Figure 4 it is also evident that for Hellenic waters fish stocks were characterised, for the same $\mathrm{K}$ values, by smaller $\mathrm{L}_{\text {oo }}$ values (i.e. the vast majority of the points are positioned below the "global" FishBase regression line). The only notable exceptions were the $X$. gladius stocks (Fig. 4). It must be stressed that the removal of the $X$. gladius stocks did not affect the slope of the "Hellenic" regression line (i.e. $\log \mathrm{L}_{\mathrm{oo}}=1.29-0.30 \operatorname{LogK}$, SE-slope $=0.09, \mathrm{r}=-0.32, \mathrm{n}=92$, $\mathrm{P}<0.05$ ).

The $\mathrm{L}_{\max } / \mathrm{L}_{\text {oo }}$ ratio (Fig. 5a) ranged between 0.56 , for $M$. merluccius, and 1.34, for Lepidorhombus boscii, with a mean and median value of 0.90 for both (Table 1).

Female $\mathrm{T}_{\text {mat }}$ was estimated for 24 stocks only and ranged from $1 \mathrm{yr}$, for $M$. barbatus, M. surmuletus and Pagellus acarne, to $6 \mathrm{yr}$, for Pagrus pagrus, with a mean and median value of 2.5 and $2.3 \mathrm{yr}$, respectively (Table 1 ).

The $\mathrm{L}_{\text {mat }} / \mathrm{L}_{\text {oo }}$ ratio (Fig. $5 \mathrm{~b}$ ) ranged from 0.33 , for $M$. surmuletus, to 0.74, for Seranus cabrilla, with a mean and median value of 0.49 and 0.48 , respectively (Table 1 ). $\mathrm{L}_{\text {mat }}$ increased with an increase in $\mathrm{L}_{\mathrm{oo}}$ and the slope of the relationship was equal to 1 and did not differ significantly (ANCOVA, P>0.05) from the slope of the same relationship for the stocks so far recorded in FishBase $98(=0.901$; Fig. 6).

The $S_{\text {oo }}$ values and the centre $\mathrm{L}_{\mathrm{oo}}, \mathrm{K}$ and $\varphi$ ' values of the four species studied are shown in Table 3 and their growth spaces in figure 7 . The overlap index between pairs of el- 


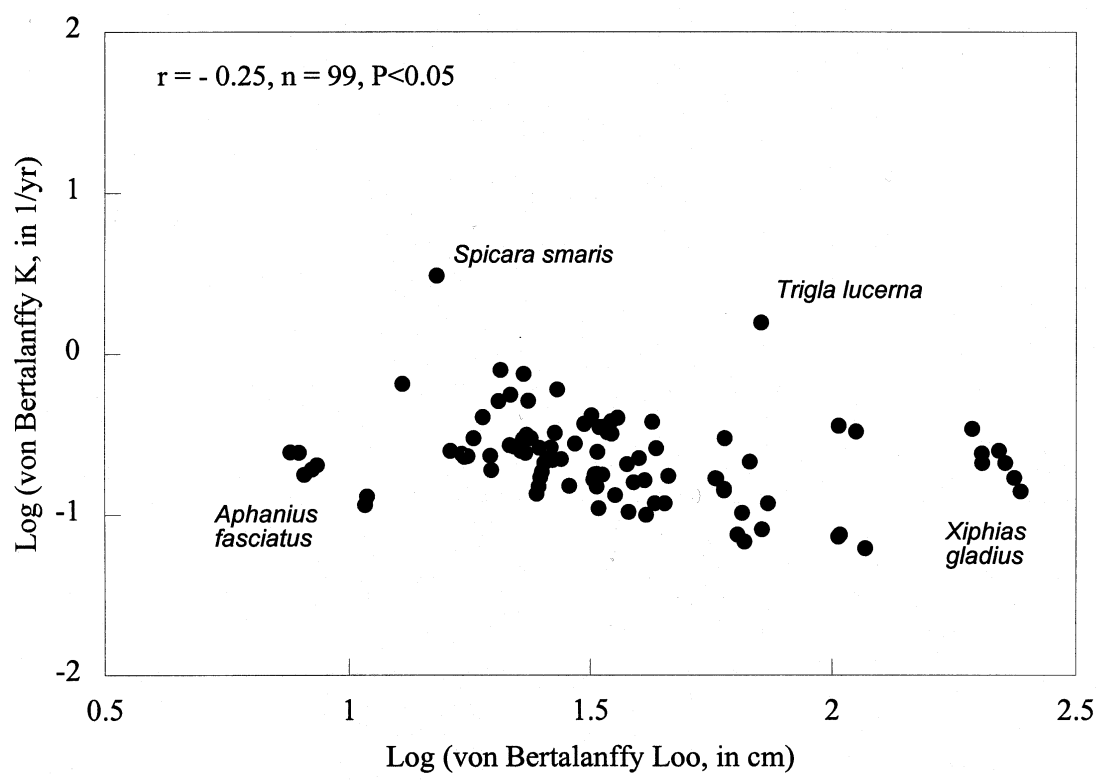

Fig. 3. Relationship between the von Bertalanffy $\mathrm{K}$ and $\mathrm{L}$ parameters for a variety of fish stocks in Hellenic waters.

lipses was 0 for all pairs of species, a fact indicating a strong dissimilarity in their growth performances, or in other words that the four species do not share similar growth spaces.

Natural mortality rates were available for 53 stocks only and ranged between $0.16 \mathrm{yr}^{-1}$, for $M$. merluccius, and 1.92 $\mathrm{yr}^{-1}$, for $A$. fasciatus, with a mean and median value of 0.51 and $0.37 \mathrm{yr}^{-1}$ and a mode at $0.3-0.4 \mathrm{yr}^{-1}$ (Fig. 8a). The natural mortality rates presented here refer to an average for post-juvenile stages whereas natural mortality rates for earlier life-history stages will be much higher (Caddy 1989). Since natural mortality rates have been estimated from the empirical formula of Pauly (1980), such estimates are not independent from the $\mathrm{K}$ and $\mathrm{L}_{\mathrm{oo}}$ values. Thus, there is not any meaning in identifying the relationship between $K$ and M. However, the $T_{\max }$ estimates are independent of the $Z$ estimates, which ranged between 0.29 and $4.82 \mathrm{yr}^{-1}$ (Fig. 8b, Table 1). Both LogK (Fig. 9) and LogZ (Fig. 10) decreased with an increase in $\log \mathrm{T}_{\max }$.

\section{Discussion}

In the present study, significant relationships were established between the life-history parameters $\mathrm{K}$ and $\mathrm{L}_{\text {oo, }} \mathrm{K}$ and $\mathrm{T}_{\max }, \mathrm{L}_{\text {mat }}$ and $\mathrm{L}_{\mathrm{oo}}$, and $\mathrm{Z}$ and $\mathrm{T}_{\max }$, for a variety of fish

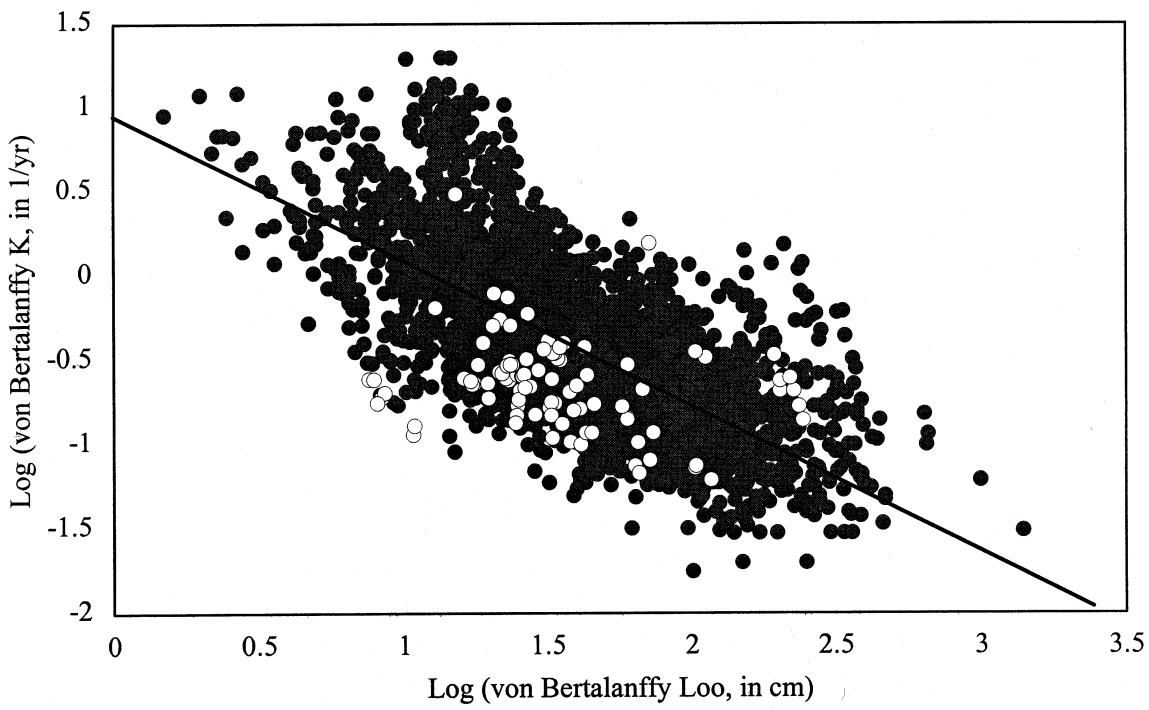

Fig. 4. Relationship between the von Bertalanffy $\mathrm{K}$ and $\mathrm{L}_{\mathrm{oo}}$ parameters for a variety of fish stocks in Hellenic waters (open circles) and for 4830 stocks registered in FishBase 98 (black circles; data from the PopGrowth table: Binohlan and Pauly 1998). The two slopes differ significantly $\mathrm{P}<0.05)$. 

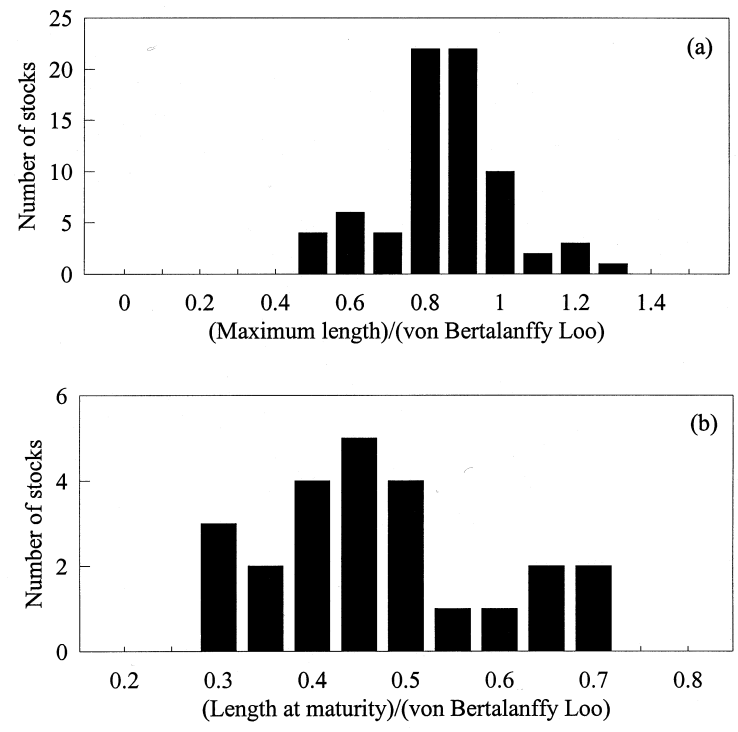

Fig. 5. The ratios of (a) maximum length over the von Bertalanffy $\mathrm{L}_{\mathrm{oo}}$ and (b) length-at-maturity over $\mathrm{L}_{\mathrm{oo}}$ for a variety of female fish stocks in Hellenic waters.

stocks in the Hellenic waters. Such relationships can be used for estimating one variable from the other for various fish stocks in that region. It must be pointed out, however, that because the data used were biased towards the larger, commercial species (84 commercial out of 103 stocks), the relationships and interpretations presented here must be considered with caution, and the data set must be expanded to include more stocks and species. It must also be stressed that the observed patterns might be a consequence of common ancestry. Yet, given the high diversity of species analysed here ( 40 species belonging to 20 families) this is likely not a problem.
It is generally well known that within a closely related group of fish stocks (e.g. order, family, genus, species), the $\log \mathrm{L}_{\mathrm{oo}}$ and $\mathrm{LogK}$ values are negatively correlated (e.g. Beverton and Holt 1959, Adams 1980, Munro and Pauly 1983, Pauly and Munro 1984, Wootton 1990, Pauly 1980, Roff 1992, Charnov 1993, Froese and Pauly 1998, Pauly 1998a). In other words, the von Bertalanffy parameters are linked by the relation $\mathrm{L}_{\mathrm{oo}}=\mathrm{DK}^{\mathrm{h}}$, with the dimensionless exponent $\mathrm{h}$, known as the Beverton-Holt invariant, generally ranging between 0.27 and 0.80 (Charnov 1993). Such a relationship shows that the faster a species approaches its $\mathrm{L}_{\mathrm{oo}}$, the smaller it is as an old adult (often termed as growth trade-off). In Hellenic waters, the value of the dimensionless number $h$ ranged between 0.18 and 0.67 , when Gadiformes are taken into account, whereas for all fish stocks considered together it was 0.32 . The latter is much smaller than that for the 4830 populations so far registered in FishBase 98, which equals 0.57 (Fig. 4). From figure 4 becomes also apparent that the stocks and/ or species inhabiting Hellenic waters are smaller than those inhabiting other areas since, as mentioned earlier, the majority of the points are located below the FishBase "global" regression line. The most notable exception was $X$. gladius, for which all seven stocks formed a clear, tight cluster to the right part of the graph and above the "global" regression line (Fig. 4). We shall return to this point later.

It is worthy to mention here that the small size of the fish species inhabiting Hellenic waters is also indicated, beyond any doubt, from the results of experimental trawl fishing, according to which the average weight per individual caught in the codends is very small when compared with other regions (e.g. as small as 20 g: Stergiou 1999a).

It is also known that in fishes the $\mathrm{L}_{\text {mat }} / \mathrm{L}_{\text {oo }}$ ratio is relatively constant within most families, being generally smaller for large-sized species and larger for small-sized ones (e.g. 0.75 for clupeids and 0.55 for cod; Beverton and Holt

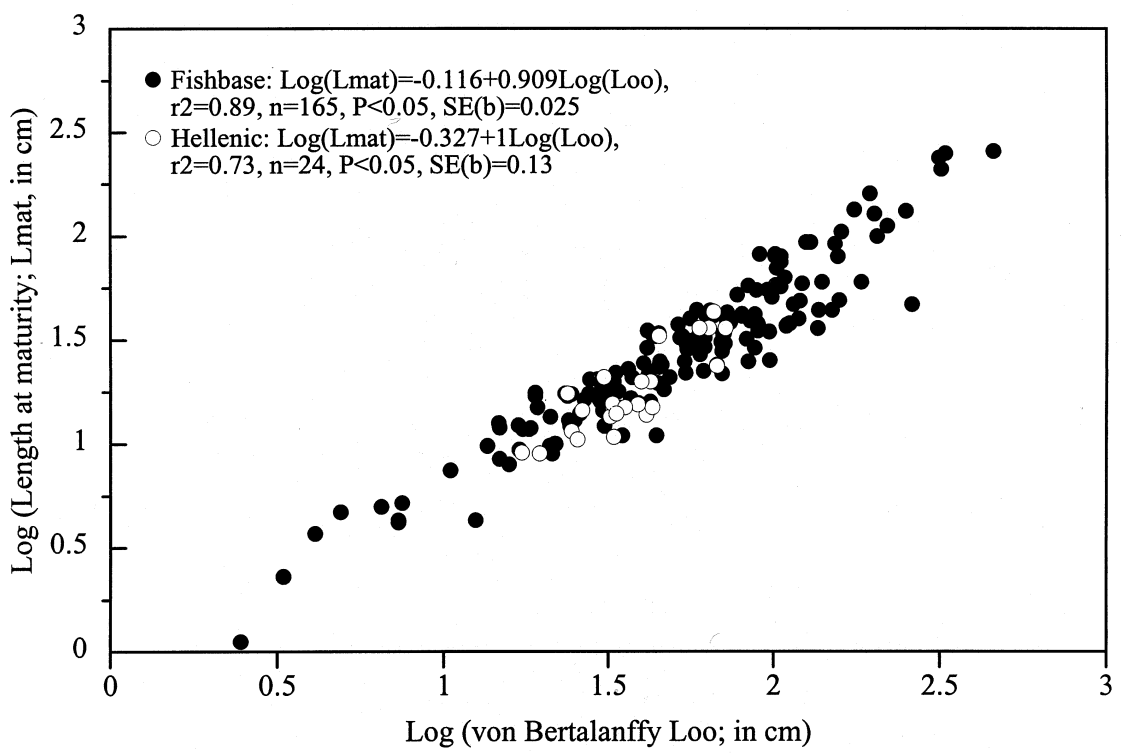

Fig. 6. Relationship between the female lengthat-maturity and the von Bertalanffy $\mathrm{L}_{\text {oo }}$ parameter for a variety of fish stocks in Hellenic waters (open circles) and for 165 stocks registered in FishBase 98 (black circles; data from the Maturity table: Binohlan 1998). The two slopes do not differ significantly (ANCOVA, $\mathrm{P}>0.05)$. 
Table 3. Asymptotic surfaces $\mathrm{S}_{\text {oo }}$ and center $\mathrm{L}_{\mathrm{oo}}, \mathrm{K}$ and $\varphi$ ' values for four fish species in the Hellenic waters. The original sets of $\mathrm{L}_{\mathrm{oo}}$ and $\mathrm{K}$ values for each stock per species are from Stergiou et al. (1997).

\begin{tabular}{|c|c|c|c|c|c|}
\hline \multirow[b]{2}{*}{ Species } & \multirow{2}{*}{$\begin{array}{l}\text { Number of } \\
\text { stocks }\end{array}$} & \multirow[b]{2}{*}{$\mathrm{L}_{\mathrm{oo}}(\mathrm{cm})$} & \multicolumn{2}{|c|}{ Center values of } & \multirow[b]{2}{*}{$S_{\text {oo }}\left(\log\right.$ unit $\left.^{2}\right)$} \\
\hline & & & $\mathrm{K}(1 / \mathrm{yr})$ & $\varphi^{\prime}$ & \\
\hline Aphanius fasciatus & 7 & 8.8 & 0.181 & 1.147 & 0.0409 \\
\hline Mullus barbatus & 11 & 25.3 & 0.199 & 2.103 & 0.1496 \\
\hline Merluccius merluccius & 9 & 76.4 & 0.095 & 2.743 & 0.2825 \\
\hline Xiphias gladius & 7 & 217.5 & 0.211 & 4.000 & 0.0631 \\
\hline
\end{tabular}

1959, Beverton 1963, Longhurst and Pauly 1987, Charnov 1993, Pauly 1994, Binohlan 1998). The $\mathrm{L}_{\text {mat }} / \mathrm{L}_{\text {oo }}$ ratio is another invariant representing the outcome of life-history symmetries (Charnov 1993). The constancy in the $\mathrm{L}_{\text {mat }}$ l $\mathrm{L}_{\mathrm{oo}}$ ratio has been attributed to the "reproductive drain concept", according to which fish grow fast until they reach $\mathrm{L}_{\text {mat }}$ and then their growth declines because most of the energy previously used for body growth is now channelled to reproduction. An alternative hypothesis, that is nowadays gaining ground, however, is that is the slow down of growth that triggers reproduction (for a discussion see: Pauly 1994, 1998a, Binohlan 1998). The female $\mathrm{L}_{\text {mat }} / \mathrm{L}_{\text {oo }}$ ratio of the 165 stocks registered in FishBase 98 ranges from 0.18 to 0.97 , with a mean and median value of 0.56 and 0.54 , respectively (Table 4 ). Those values are somewhat larger than those of the Hellenic stocks (Table 1) and may indicate that the relative length at maturity of the Hellenic fishes is lower. The relationship between $\mathrm{L}_{\text {mat }}$ and $\mathrm{L}_{\mathrm{oo}}$ for both the Hellenic fishes and those included in FishBase 98 (Fig. 6) was linear with unit slope for the former ones that did not differ from the latter one. This makes $\mathrm{L}_{\text {mat }} / \mathrm{L}_{\text {oo }}$ a constant equal to 0.47 for the Hellenic stocks, i.e. close to their mean $\mathrm{L}_{\text {mat }} / \mathrm{L}_{\mathrm{oo}}$ ratio (Table 1), and equal to 0.77 for those included in FishBase.

Winemiller and Rose (1992) analysed the life-history patterns of 216 North American marine and freshwater fish species, belonging to 57 families. Their data set was also biased towards the larger, commercial species, with the marine ones belonging to similar orders with those of the Hellenic stocks (i.e. Perciformes, Scorpaeniformes, Pleuronectiformes, Clupeiformes; the only exception was Salmoniformes, which was not represented in Hellenic waters). Thus, one may hypothesise that both data sets represent "ecologically" equivalent species arrays. As a group, the Hellenic fishes were smaller $($ mean $=43.6 \mathrm{~cm})$, had shorter life spans $($ mean $=7.02 \mathrm{yr})$ and matured earlier

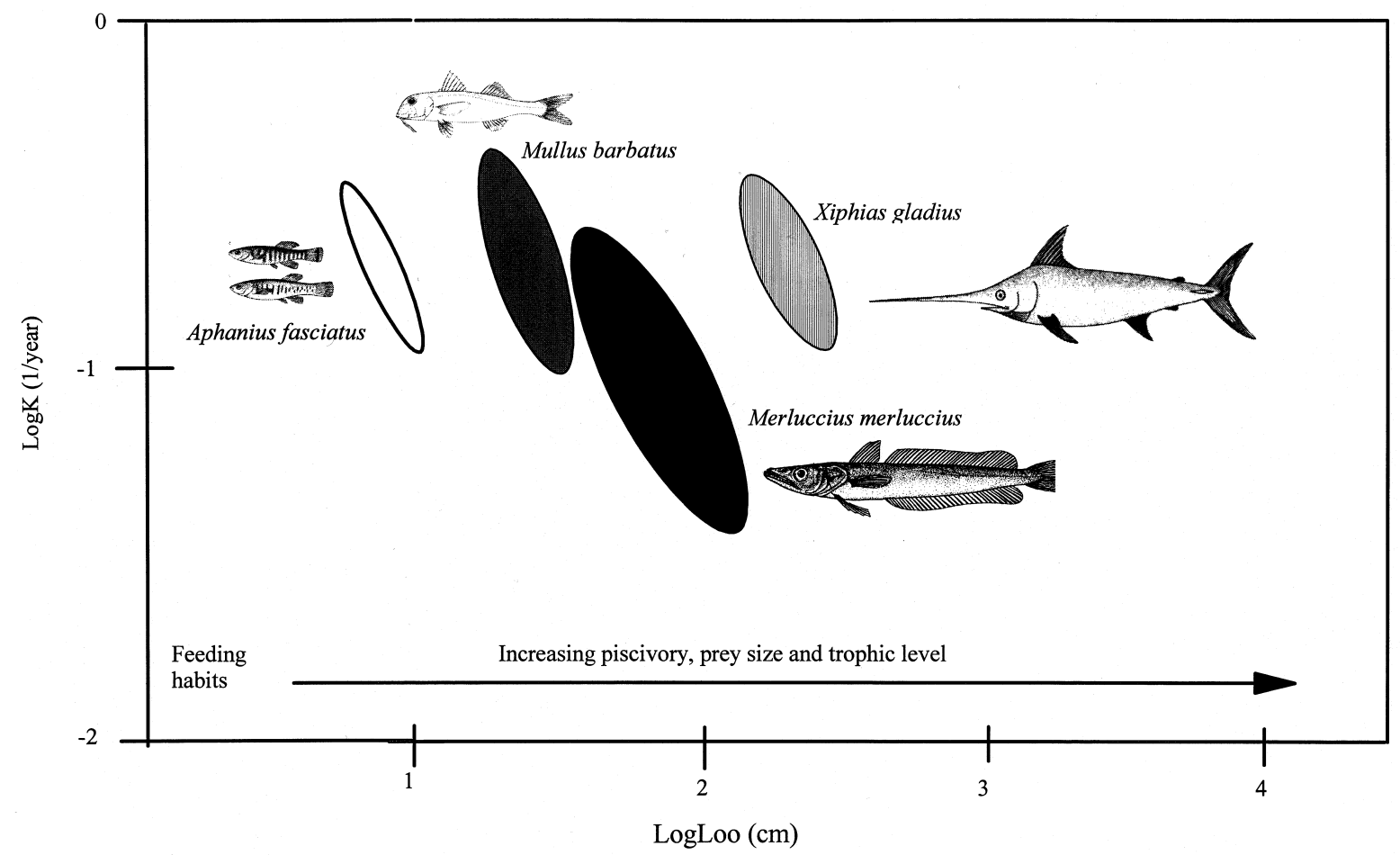

Fig. 7. Auximetric grid showing asymptotic growth surfaces for four species in the Hellenic waters. 

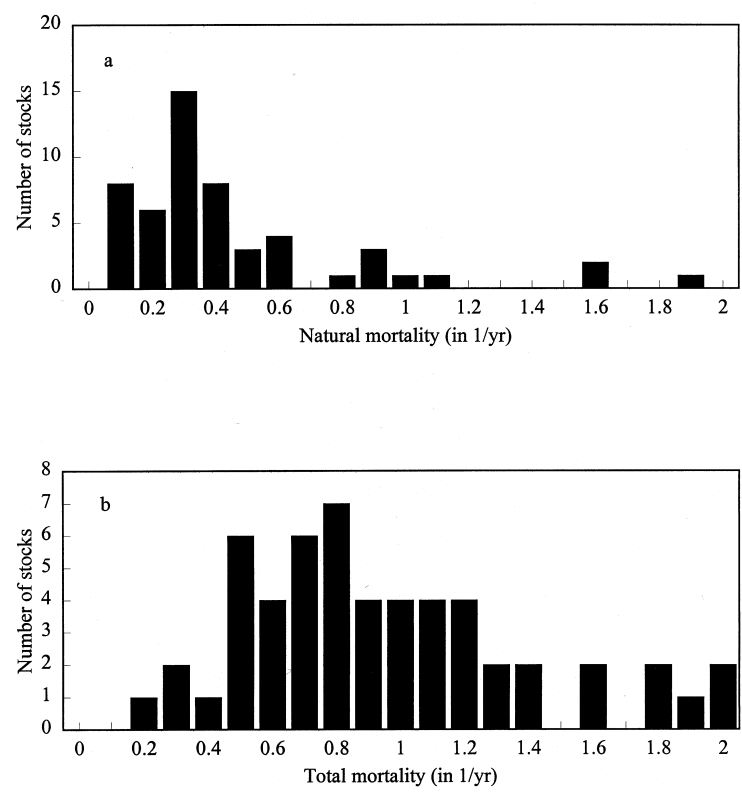

Fig. 8. (a) Natural and (b) total mortality rates for a variety of fish stocks in Hellenic waters.

$($ mean $=18.6 \mathrm{~cm}$ and $2.5 \mathrm{yr})($ Table 1$)$ than their North American marine counterparts (mean $=55.1 \mathrm{~cm}, 13 \mathrm{yr}, 32$ $\mathrm{cm}$ and $3.4 \mathrm{yr}$, respectively). The mean $\mathrm{L}_{\text {mat }}$ of the Hellenic stocks (Table 1) was also smaller than that of the FishBase stocks used for the estimation of the $\mathrm{L}_{\text {mat }}-\mathrm{L}_{\text {oo }}$ relationship (Table 4).

The $M$ rates for the Hellenic waters were estimated from the empirical equation of Pauly (1980), which was based on data from 175 fish stocks (in this data set the Hellenic stocks were largely underrepresented). The $M$ rates of 175 fish stocks range from 0.1 to $7.8 \mathrm{yr}^{-1}$ and modal natural mortality is $0.2-0.3 \mathrm{yr}^{-1}$. The latter is lower than that in the Hellenic waters (Table 1, Fig. 8a), a fact possibly indicating that Hellenic stocks generally suffer from high post-juvenile mortality rates.

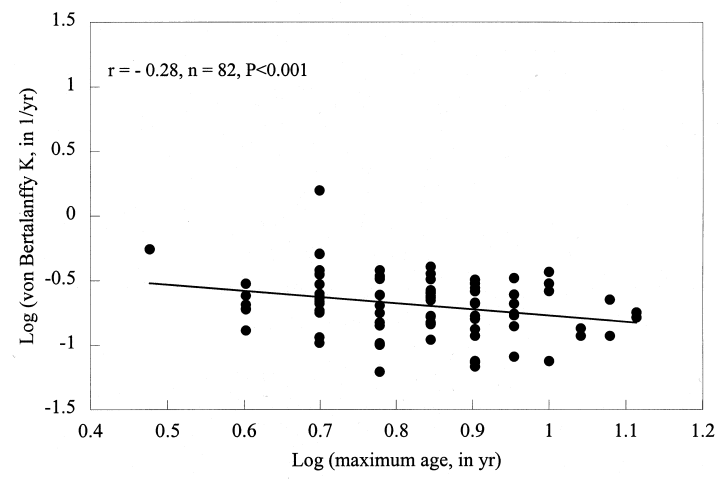

Fig. 9. Relationship between maximum age and the von Bertalanffy $\mathrm{K}$ parameter for a variety of fish stocks in Hellenic waters.
To sum up, the fish stocks and/or species inhabiting the Hellenic waters are generally small in size, have low longevity, mature at an early age and size, and probably suffer high adult mortality rates. Such a pattern most probably is an adaptation to the synergetic combination of highly oligotrophic conditions and high subtropical temperatures prevailing in Hellenic waters (Stergiou 1993, 1999b, Stergiou et al. 1997) and is consistent with life-history theory. Thus, low trophic potential combined with relatively high temperatures lead to low growth rates. This most probably implies small body sizes, thus increasing both the time spent and the intensity of different size-related predatory fields (for a discussion on the relationship between $\mathrm{M}$ and temperature see also: Pauly 1980, 1998a,b, Pauly and Binohlan 1998). Life-history theory predicts that, under conditions of age- or size-specific mortality rates and when adult survival is low and uncertain, the individuals of a population may increase their fitness by decreasing their length-at-maturity when compared with those from an environment characterised by a higher adult survival (e.g. Wootton 1990, Stearns 1992, Roff 1992). The benefit of early maturation springs from the fact that early maturing individuals have a higher probability of surviving to maturity (Bell 1980). Now we may return to the exception of Xiphias gladius, which is a highly migratory species, and because of such a habit its growth is less affected from local environmental (i.e. food, temperature) conditions.

Various empirical studies also reveal that $\mathrm{M}$ and $\mathrm{K}$ are positively related (e.g. Beverton and Holt 1959, Pauly 1980, 1994, 1998a,b, Roff 1992, Pauly and Binohlan 1998 ), with the $\mathrm{M} / \mathrm{K}$ ratio representing another life-history invariant (Charnov 1993; but see Pauly 1998b). As mentioned earlier, the $\mathrm{M}$ estimates of the Hellenic stocks are not independent from their $\mathrm{K}_{\text {and }} \mathrm{L}_{\mathrm{oo}}$ values. Thus, in the present study the relationship between $\mathrm{K}$ and $\mathrm{M}$ as well as the $\mathrm{M} / \mathrm{K}$ ratio were not estimated. The negative relationship between $\mathrm{K}$ and $\mathrm{T}_{\max }$ (Fig. 9) is a reflection of the negative relationship between $M$ and $T_{\max }$ (and between $Z$ and $T_{\max }$ : Fig. 10). $T_{\max }$ is a well-behaved statistic for large samples and $1 / \mathrm{T}_{\max }$ approximates M (e.g. Beverton 1963,

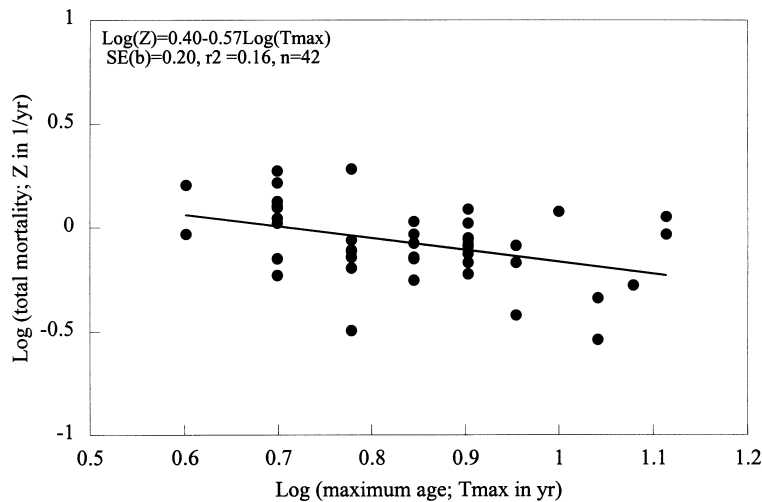

Fig. 10. Relationship between maximum age and total mortality for a variety of fish stocks in Hellenic waters. 
Table 4. Statistical analysis of the female length-at-maturity $\left(\mathrm{L}_{\text {mat }}\right)$ and of the ratio of $\mathrm{L}_{\text {mat }}$ over the von Bertalanffy $\mathrm{L}_{\text {oo }}$ for the stocks included in FishBase 98.

\begin{tabular}{lrrrrrr}
\hline Parameter & Minimum & Maximum & Mean & Stand. dev. & Median & Number \\
\hline $\mathrm{L}_{\text {mat }}$ & 1.12 & 257 & 39.7 & 42.03 & 29.3 & 165 \\
$\mathrm{~L}_{\text {mat }} \mathrm{L}_{\text {oo }}$ & 0.18 & 0.97 & 0.56 & 0.15 & 0.54 & 165 \\
\hline
\end{tabular}

Hoenig 1983, Charnov 1993). Hence, M and K both show how quickly a species "reaches" its death.

In the present work, the auximetric grid was used for comparing the growth of four species, each represented by more than six stocks. Growth performance in fishes strongly depends, among other things, on the quality and quantity of food consumed (e.g. Wootton 1990) and generally a fish diet is superior to a benthic or plankton one (e.g. Martin 1966). Indeed, the growth spaces occupied by the four species seem to reflect their strikingly different feeding habits, especially with respect to the size of prey and the relative importance of fish prey to their diet (Fig. 7). Hence, growth potential as well as ?' values were all lower for A. fasciatus, a lagoonal, small-sized species feeding on vegetal material, detritus and small invertebrates (Whitehead et al. 1986), and much higher for X. gladius. (Fig. 7, Table 3). The latter is a large pelagic, primary piscivore species (sensu Keast 1985), feeding exclusively upon medium-sized pelagic fishes (e.g. Scomber spp., Trachurus spp., Caranx spp.) and squids (Whitehead et al. 1986). The growth potential of $X$. gladius is followed by that of $M$. merluccius, a large-sized demersal species, which feeds upon crustaceans and small-sized fishes when smaller than $20 \mathrm{~cm}$ total length, and almost exclusively upon small-tomedium sized fishes when larger than $20 \mathrm{~cm}$ (e.g. Argentina sphyraena, Sardina pilchardus,Engraulis_encrasicolus, Spicara_spp.,_Trachurus_spp.,_Gadiculus_argenteus argenteus ${ }_{2}$ Gobius_spp.,_Serranus hepatus) (Papaconstaninou and Stergiou 1995). The growth space between $A$. fasciatus and $M$. merluccius is occupied by $M$. barbatus ${ }_{2}$ which is a mediumsized benthic species feeding mainly upon benthic invertebrates, such as amphipods, decapods, polychaetes, gastropods and bivalves, and to a much lesser extent upon smallsized fishes such as Gobius spp. and_Gaidropsarus mediterraneus (Caragitsou and Tsimenides 1982, Vassilopoulou and Papaconstantinou 1993, Lambropoulou 1997).

\section{References}

Adams, P. B. 1980. Life history patterns in marine fishes and their consequences for fisheries management. - Fish. Bull. U.S. 78: 1-12.

Bell, G. 1980. The costs of reproduction and their consequences. - Am. Nat. 116: 45-76.

von Bertalanffy, L. 1938. A quantitative theory of organic growth (Inquires on growth laws. II). - Hum. Biol. 10: 181-213.
Binohlan, C. 1998. The maturity table. - In: Froese, R. and Pauly, D. (eds.), FishBase 98: Concepts, design and data sources. Manila: ICLARM, pp. 176-179.

Binohlan, C. and Pauly, D. 1998. The PopGrowth table. - In: Froese, R. and Pauly, D. (eds.), FishBase 98: concepts and design data sources. Manila: ICLARM, pp. 124-129.

Beverton, R. J. H. 1963. Maturation, growth and mortality of clupeid and engraulid stocks in relation to fishing. - Rap. P. V. Reun. Cons. Int. Expl. Mer 154: 44-67.

Beverton, R. J. H. and Holt, S. J. 1959. A review of the lifespans and mortality rates of fish in nature, and their relation to growth and other physiological characteristics. - In: Wohstenholme, G. E. and O'Conner, M. (eds.), CIBA Foundation Colloquia on ageing. Vol. 5. The lifespan of animals. Churcill, London, pp. 142-180.

Caddy, J. F. 1989. A note for fishery workers in the Eastern Mediterranean on the estimation of values for M. - FAO Fish. Rep. 412: 199-200.

Caragitsou, E. and Tsimenides, N. 1982. Seasonal changes and comparative analysis of the food of the red mullet (Mullus barbatus) in the gulfs of Saronikos and Thermaikos. - Thalassographica 5: 41-61.

Charnov, E. 1993. Life history invariants. - Oxford Series in Ecology and Evolution. Oxford: Oxford University Press.

Francis, R. I. C. C. 1996. Do herring grow faster than orange roughy? - Fish. Bull. (U.S.) 94: 783-786.

Froese, R. and Pauly, D. (eds.). 1998. FishBase 98: Concepts, design and data sources. -Manila: ICLARM.

Gunderson, D. R. and Dygert, P. H. 1988. Reproductive effort as a predictor of natural mortality rate. - J. Cons. Int. Explor. Mer 44: 200-209.

Hoenig, J. M. 1983. Empirical use of longevity data to estimate mortality rates. - Fish. Bull. (U.S.) 81: 898-903.

Jennings, S. and Beverton, R. J. H. 1991. Intraspecific variation in the life history tactics of Atlantic herring (Clupea harengus L.) stocks. - ICES J. Mar. Sci. 48: 117-126.

Keast, A. 1985. The piscivore feeding guild of fishes in small freshwater ecosystems. - Env. Biol. Fish 12: 119-129.

Labropoulou, M. 1997. The feeding ecology of two sympatric Mullus species in Iraklion Bay. - Proc. $5^{\text {th }}$ Hellenic Symp. Oceanog. Fish. 5: 67-70.

Longhurst, A. and Pauly, D. 1987. Ecology of tropical oceans. San Diego: Academic Press.

Martin, N. V. 1966. The significance of food habits in the biology, exploitation, and management of Algonquin Park, Ontario, Lake trout. - Trans. Amer. Fish. Soc. 95: 415-422.

Moreau, J., Bambino, C. and Pauly, D. 1986. A comparison of four indices of overall fish growth performance, based on 100 tilapia populations (Fam. Cichlidae). - In: Maclean, J. L., Dizon, L. B. and Hosillos, L. V (eds.), The First Asian Fisheries Forum. Asian Fisheries Society, Manila, Philippines, pp. 201-206. 
Munro, J. L. and Pauly, D. 1983. A simple method for comparing the growth of fishes and invertebrates. - Fishbyte 1(1): 56.

Papaconstantinou, C. and Stergiou, K. I. 1995. Biology and fisheries of hake, Merluccius_merluccius L., 1758, in the eastern Mediterranean. - In: Alheit, J. and Pitcher, T. J. (eds.), Hake, fisheries products and markets. Fish and Fisheries Series 15. London: Chapman \& Hall, pp. 149-180.

Pauly, D. 1980. On the interrelationships between natural mortality, growth parameters and mean environmental temperature in 175 fish stocks. - J. Cons. Int. Explor. Mer 39: 175192.

Pauly, D. 1983. Length-converted catch curves: a powerful tool for fisheries research in the tropics (Part I). - Fishbyte 1(2): 913.

Pauly, D. 1994. On the sex of fish and the gender of scientists: a collection of essays in fisheries science. - Fish and Fisheries Series 14. London: Chapman and Hall.

Pauly, D. 1997. Geometrical constraints on body size. - Tr. Ecol. Evol. 12: 442-443.

Pauly, D. 1998a. Tropical fishes: patterns and propensities. - J. Fish Biol. 53 (Suppl.): 1-17.

Pauly, D. 1998b. The natural mortality of fishes. - In: Froese, R. and Pauly, D. (eds.), FishBase 98: Concepts, design and data sources. Manila: ICLARM, pp. 138.

Pauly, D. and Munro, J. L. 1984. Once more on growth comparison in fish and invertebrates. - Fishbyte 2(1): 21.

Pauly, D. and Binohlan, C. 1998. Natural mortality. - In: Froese, R. and Pauly, D. (eds.), FishBase 98: Concepts, design and data sources. Manila: ICLARM, pp. 137-140.

Pauly, D., Moreau, J. and Gayanilo, F. Jr. 1996. A new method for comparing the growth performance of fishes applied to wild and farmed tilapias. - In: Pullin, R. S. V., Lazard, J., Legendre, M., Amon Kothias, J. B. and Pauly, D. (eds.), The Third International Symposium on Tilapia in aquaculture. ICLARM Conf. Proc. 41: 433-441.

Pauly, D., Christensen, V., Dalsgaard, J., Froese, R. and Torres, F. C. 1998. Fishing down marine food webs. - Science 279: 860-863.
Roff, D. A. 1992. The evolution of life histories: theory and analysis. - London: Chapman and Hall.

Stearns, S. C. 1992. The evolution of life histories. - Oxford: Oxford University Press.

Stergiou, K. I. 1993. Nutrient-dependent variation in growth and longevity of the red bandfish, Cepola macrophthalma (L.), in the Aegean Sea. - J. Fish Biol. 42: 633-644.

Stergiou, K. I. 1999a. Effects of changes in the size and shape of codend on catch of Aegean Sea fishes. - ICES J. Mar. Sci. 56: 96-102.

Stergiou, K. I. 1999b. Intraspecific variations in size- and age-atmaturity for red bandfish, Cepola macrophthalma. - Env. Biol. Fishes 54: 151-160.

Stergiou, K. I., Christou, E. D., Georgopoulos, D., Zenetos, A. and Souvermezoglou, C. 1997. The Hellenic seas: physics, chemistry, biology and fisheries. - Oceanog. Mar. Biol. Ann. Rev. 35: 415-538.

Vakily, J. M. 1992. Determination and comparison of bivalve growth, with emphasis on Thailand and other tropical areas. - ICLARM Tech. Rep. 36: 1-125.

Vassilopoulou, V. and Papaconstantinou, C. 1993. Feeding habits of red mullet (Mullus barbatus) in the North Aegean Sea. Proc. 4th Hellenic Symp. Oceanog. Fish. 4: $491-492$ (in Hellenic, English abstract).

Whitehead, P. J. P., Bauchot, M. L., Hureau, J. C., Nielsen, J. and Tortonese, E. (eds). 1986. Fishes of the North-eastern Atlantic and the Mediterranean. - Volumes I, II and III. Paris: UNESCO.

Winemiller, K. O. and Rose, K. A. 1992. Patterns of life history diversification in North American fishes: implications for population regulation. - Can. J. Fish. Aquat. Sci. 49: 21962218.

Wootton, R. J. 1990. Ecology of teleost fishes. - Fish and Fisheries Series 1, London: Chapman and Hall.

Appendix: List of species per family used in the analysis (from Stergiou et al. 1997; species names according to Whitehead et al. 1986).

Carangidae: Trachurus mediterraneus, Trachurus trachurus; Centracanthidae:_Spicara smaris,_Spicara flexuosa; Cepolidae: Cepola macrophthalma; Citharidae: Citharus linguatula; Clupeidae: Sardina pilchardus; Cynoglossidae: Symphurus ligulatus; Cyprinodontidae: Aphanius fasciatus; Gadidae: Gadiculus argenteus argenteus,_Merlangius merlangus euxinus,_Micromesistius poutassou, Gaidropsarus mediterraneus,_Phycis blennoides,_Trisopterus minutus capelanus; Lophiidae: Lophius budegassa,_Lophius piscatorius; Merluccidae: Merlucius merluccius; Mugilidae: Chelon labrosus,_Liza aurata,_Liza ramada,_Liza saliens; Mullidae:_Mullus barbatus, Mullus surmuletus; Scaridae: Sparisoma cretense; Scombridae: Thunnus alalunga; Scophthalmidae: Lepidorhombus boscii; Serranidae: Serranus cabrilla; Soleidae: Solea vulgaris; Sparidae: Boops boops,_Pagellus acarne,_Pagellus bogaraveo, Pagellus erythrinus,_Pagrus pagrus; Triglidae: Aspitrigla cuculus,_Eutrigla gurnardus,_Trigla lucerna,_Trigla lyra,_Trigloporus lastoviza; Xiphiidae: Xiphias gladius. 